\title{
Research on Economic Development Stage and Marginal Effects of Trade and FDI on Economic Growth in China
}

\author{
Limin $\mathrm{Yao}^{1}$, Chaobo $\mathrm{Bao}^{1} \&$ Junliang $\mathrm{Yu}^{1}$ \\ ${ }^{1}$ College of Business and Administration, Zhejiang University of Technology, Hangzhou, China \\ Correspondence: Yao Limin, College of Business and Administration, Zhejiang University of Technology, \\ Hangzhou, 310023, China. E-mail: ylm@zjut.edu.cn
}

Received: August 29, 2013

Accepted: September 13, $2013 \quad$ Online Published: October 26, 2013

doi:10.5539/ijef.v5n11p37

URL: http://dx.doi.org/10.5539/ijef.v5n11p37

\begin{abstract}
Since reform and opening up. exports and FDI, as two main internationalization patterns, successfully promote China's economic growth and increase the per capita income. In the mean time, it widens the regional economic gap. Whether exports and FDI are still two engines to promote China's economic growth in a new stage of development? This paper collects provincial panel data from 1987 to 2010 in China with three economic areas, the east, the middle, and the west, and divides them into two periods, before entry into WTO and after, to study the stage of economic development's growth effect on trade and FDI empirically. It concludes that the developed eastern area's exports have the strongest promotion effect on economy, but its promotion effect is weakening now and weaker than the imports' promotion effect which is still increasing now, in the compared undeveloped mid and west of China. Furthermore, FDI's growth effects on all the three economic areas are increasing. In a word, foreign trade and FDI's growth effects change periodically in the different stages of development, so the policy mix of trade and FDI need to be adjusted with economic development.
\end{abstract}

Keywords: foreign trade, Foreign Direct Investment (FDI), economic growth, stage of economic development, marginal effect

\section{Introduction}

Since the reform and opening up, it shows rapid economic growth in most regions of China, with widening regionaleconomic gap, especially between the eastern area and the mid and west of China. The GDP per capital of eastern area is CNY 458 in 1978, it increased to CNY 45511 in 2010; In the mid per capital GDP rises from CNY 311 in 1978 to CNY 24871 in 2010; In the same period, in the west GDP per capital rises from CNY 258 to CNY 22570. It concludes that the regionaleconomic gap is widening now. Under this circumstance, different development trends appear in different areas. Exports of the eastern area increases rapidly from CNY 1.0674 trillion in 1996 to CNY 18.1862 trillion in 2010, accounting for 91\% of the whole China's exports. Although the export trade develop well in the mid and west of China, it is still in inferior comparing eastern area, particular the most undeveloped west part of China. What's more, the imports volume and exports volume show the same variation trend. Since 1980s, inward foreign direct investment (FDI) became the main pattern of international capital circulation and prime source of domestic investment; however, FDI in China is of imbalance distribution, and the eastern area occupies $80 \%$.

China joined the WTO at the end of 2001 and the general tariff level went down from $15.3 \%$ in 2002 to $9.8 \%$ in 2008 , non-tariff barrier is also phasing out, trade barriers decline stimulates foreign trade growth of all the areas. In addition, after joined the WTO, the proportion of labor intensive products exports continue to decrease, the proportion of capital-and technology-intensive products exports increase, and the proportion of resource-intensive products imports increase rapidly. It indicates that China's import and export structure and regional economic structure are undergoing a process of qualitative change. the FDI policy are more open, transparent and friendly. FDI expands, particularly in the mid and west, many areas where were not allowed invest in the past are released, all the areas attract large amount of foreign investment.

However, in different stages of development, what indeed the promotion effects of different export, import and FDI is? How do the promotion effects change with the development? do promote the regional economic growth at different levels of economic? Considering the economic growth's factor-driven theory and economic development level, this paper studies the different import, export, and FDI' promotion effects on economic 
growth in different stages of development empirically, and offer suggestion to international policy adjustment.

\section{The Evolution of Economic Growth Factors and Related Literature Review}

\subsection{Stages of Economic Development and Factors Evolution of the Economic Growth}

At different stages of economic development, there have been classical theories on the internationalization factors (import, export, FDI) which promoting economic growth. KanameAkamatsu (1932) put forward Flying Geese Paradigmechelon (industrial development patterns) which discusses the growth pattern transformation of developing country from import-driven to export-driven (process of changing: import $\rightarrow$ domestic production $\rightarrow$ export). From the perspective of the industry life cycle, Vernon (1966) presented the role evolution of four kinds of internationalization models, import, FDI, export and ODI in industry life cycle. Dunning (1981) proposed Investment Development Cycle theory and divided overseas direct investment to four phases in different developing stages and illustrated the key promotion effects of FDI and outward foreign direct investment (OFDI) In a word, it concludes that the role evolution of four promotion factors, import, export, FDI, and ODI in different stages of development.

According to the Investment Development Cycle theory (Dunning, 1981), when GDP per capita is less than $\$ 400$, there are fewer FDI, and no OFDI; when GDP per capita is between $\$ 400$ and $\$ 1500$, the country's FDI attraction ability increases obviously and is flooded with FDI, but it can't make full use of FDI because of underdevelopment; when GDP per capita is between \$2000 and \$4750, OFDI rises sharply, which probably overweigh the inflow of FDI, in the meantime, the FDI utilization efficiency is higher now; when GDP per capita is more than $\$ 5000$, which become the middle- and high-income country, the net OFDI presents positive growth, with high foreign capital utilization efficiency, promotes the economic growth of high-efficiency. This paper only take the FDI scale change into consideration.

Based on industry life cycle theory (Vernon, 1966), when a country ranks in low income countries, the products are mainly exported to low income countries due to the price elasticity of new products in developed countries are higher than in developing countries, therefore, at this stage, low-income countries import more to meet domestic demand and to promote economic growth; With the development of low-income countries, which per capita income reach lower middle income level, local production will reach economy of scale when the large enough local market lead to local entrepreneurs product themselves and probably sell the products at the price less than the import price. Even though net import still exists at this time, export-driven economic growth appears. When a country reaches medium high income level, the monopolistic technology of developed countries also diffuse to the country. With relative stabilization of technology and expanding market, local enterprises have not been restricted by scale and cost, and their production is growing, as a result they increase exports and began to export to the place of origin, then export-oriented foreign trade greatly stimulate economy growth.When a country (A) enters into the developed countries ranking, it has pure standardization products. The products' comparative advantage have been transferred to developing countries and areas where technology and wages are lower and labor resource are abundant, and these countries (B) become the mature products exporter, while the country A becomes importer of these products, with diminished export capacity and increasing import driven growth, A and B' changing scales lead to their pushing forces change. Because every industry will experience an evolution from growth to the recession, so we can analyze the pushing force of import and export on economic growth from the macroscopic perspective.

Based on the above analysis, we can roughly expect that at different levels of economic development, import, export, FDI and other international factors will change of scale and function when the level of economic development improve. We can also generally expected when the scale of import, export and FDI gets larger, pulling effect on the economy will be more powerful; The smaller on the scale of import, export and FDI, the weaker stimulating effect on the economy. But when the scale of trade and FDI reached a certain level, the effect on promoting economic growth will get weakened because of other factors' restriction. Therefore, the status change on the international push factors of economic growth will be shown in Figure1 and Figure 2. 


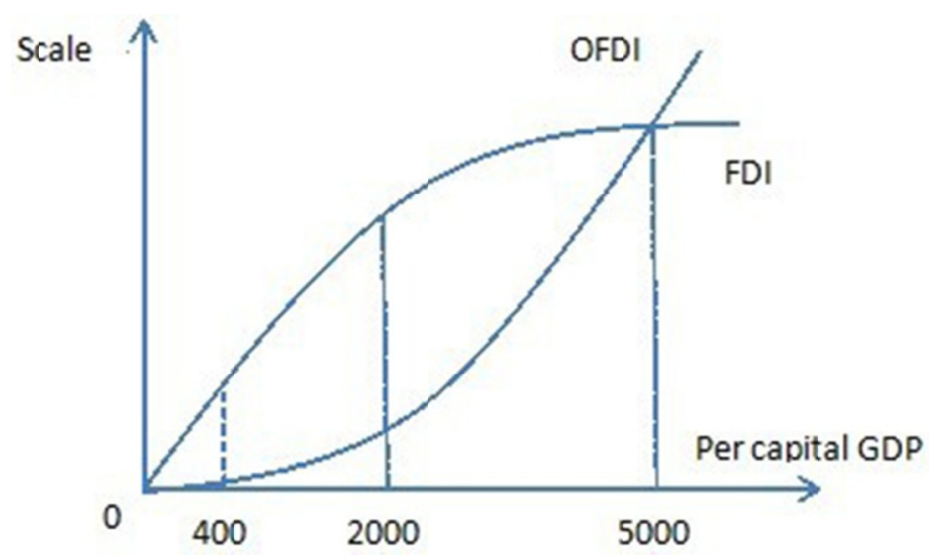

Figure 1. The relationship between the scale of FDI, OFDI and the level of economic development

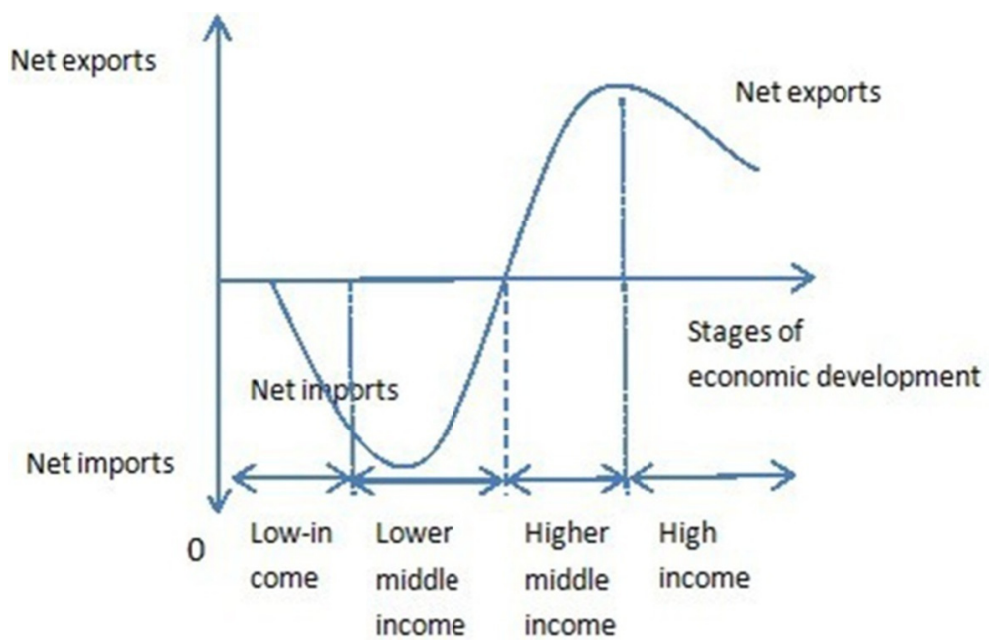

Figure 2. Industry import and export cycle evolutionand the stages of economic development

\subsection{Main Research on the Relationship between Foreign Trade, FDI and Economic Growth}

There has a lot of literatures about trade, FDI which can promote economic growth, but most research focus on the one single internationalization pattern effects on economic growth. It is much less literature about the level of economic development and industrial development cycle which combined to study the internationalization patterns promoting economic growth.

The research on relationship between exports and economic growth: Feder (1982) thought that the efficient management of the export sector will generate spillover effects on the non-export sector, thereby stimulating economic growth; Balassa (1978) using OLS regression analysis to regress the export data of 12 developing countries from 1961-1974 with GDP data, considering the contribution of labor force growth and FDI, analysis the relationship between the average GDP growth rate and the actual export growth, the studies show that export promote the country's economic growth. Kwan Kwok (1995), John Thornton (1996), Shan Sun (1998) use empirical anaylsis methods, through co-integration analysis method and Granger causality test, indicate that exports can promote economic growth. Lin Yifu, Li Yongjun (2003) improved the traditional measure of foreign trade contribution to economic growth, emphasize the effects of two parts of consumption and investment in national income identity, the use of demand-oriented analysis showed that since the $20^{\text {th }}$ century 1990 's, for each export growth of $10 \%, 1 \%$ GDP growth would be promoted; Shi Chanyu, Wang Yafei, Wang Ke (2003), XuHelian Lai Mingyong (2002), Fan Bainai, Mao Xiaotai, Wang Shuang (2005) use Granger causality test analyze the relationship between export trade and economic growth.

In the import aspect: Lee (1995), Coe (1997) demonstrated that imports play an active role in promoting 
economic growth; Liu Xiaopeng (2001) used GDP and trade data analyzing with cointegration, revealed that the growth of import is more significant in promoting the economic growth and as the driving force for economic growth; Fan Bainai, Wang Yibing (2004) empirically analysis the China's import trade and economic growth which mutually exist causal relationship. The results show that economic growth can strongly promote the import trade, while import trade can also promote the economic growth.

As for research about FDI, Kueh (1992) discussed the impact of FDI on domestic investment, industrial output and export in China's coastal areas. He found that FDI contributed much to the formation of total capital; Chinese scholar Jiang (2004) found that FDI influences Chinese economic growth through effect of capital and spillover, which plays an vital role in boosting Chinese economic growth; Cao Wei (2005) proposed that FDI, by affecting Chinese foreign trade, stimulates Chinese economic growth. However, it didn't obviously promote human capital and has a Crowding-Out Effect; Cheng Huifang (2002) proposed that the influence of growth of FDI inflows on economic growth in high-income countries is more obvious, compared to middle-income developing countries. Wang Zhiping, Zinai (2004) consider the quasi FDI spillovers' endogenous growth model, which shows that one country's long-term growth depends on the proportion of FDI and domestic capital. DeMello (1999) found out that whether the host country is a leader or a follower in technical position, FDI has a positive impact on output growth.

There is literature on combination research of trade and FDI. Lee (2006) analyzed IFDI, OFDI, intermediate product import and spillover of international technology through non-physical channel. Wang and Zhang (2005) conducted an empirical analysis of relationship between trade of Yunnan and FDI and economic growth, which showed that there is no long-term equilibrium relationship between Yunnan's exports, imports and GDP in China Yao and Wei (2007), using Petroni's panel unit root test and Arellano and Bond's dynamic panel data estimation techniques, found that export trade and foreign investment have a significant positive effect on economic growth. Mao and Yao (2009), using panel data model, analyzed the influence of foreign trade and FDI on economic growth in the eastern region. Research showed that foreign trade promotes the eastern region's economic growth significantly. Although FDI plays a negative impact on economic growth of the eastern region, the effect intensity is very small.

At the aspect of the empirical research of the economy level and foreign trade and investment promotion, XuHelian and Luan Yongyu (2005) divided the economic system into non-export sector, primary products exports sector and manufactured goods export sector, which build a three-sector model of export trade. The model is divided into two periods of Eighth five-year plan and Ninth five-year plan. They collected the section data from each region to conduct the empirical analysis to examine the technology spillover effect change of export trade to domestic non-export sector. Yao Limin, etc. (2011) comparatively studied the promotion pattern of economic growth of the eastern, central and western areas of China by using two dimensions of internationalization and factors promotion, which revealed the combination differences and evolution of imports, FDI, export-driven and lower elements and innovation-driven of the three regions of China. But for the stage of economic development and export, FDI and promote economic growth, how the effects of contact there is no clear proof. Song Yongji (2012) using Dunning investment cycle theory, conducted the empirical research about the relationship between foreign direct investment of China and the level of economic development. The results show that China's foreign direct investment is basically similar with the first four phases of Dunning investment cycle theory.

This paper is different from the existing literature, using the methods of comparative analysis, analysis the strength and change trend of three kinds of internationalization drivers which are export, import and FDI to economic growth effect, from a dynamic perspective scanning differences in levels of economic development. The purpose of this paper is providing ideas for policy adjustments and more effectively promote regional economic growth.

\section{Data Processing and Empirical Analysis}

\subsection{Data Sources and Processing}

The data is mainly from the "China Statistical Yearbook" and "New China 60 years compilation", the sample data is the 1987-2010 annual data, according the exchange rate, we translate the data of import, export and FDI into one million Chinese yuan, in order to exclude the price factor, using the original data of nominal GDP through GDP deflator transformed into real GDP. Natural logarithmic transformation of data does not change the original cointegration relationship, and does also eliminate the time series heteroskedasticity, thus, transformed the FDI, GDP, import and export into natural logarithmic, and expressed by LnGDP represents the level of economic growth, EX represents the export value, IMP represents the value of imports, FDI represents the actual 
use of foreign direct investment, TRA represents the total import and export trade. This paper selected eastern region which include Beijing, Tianjin, Hebei, Liaoning, Shanghai, Jiangsu, Zhejiang, Fujian, Shandong, Guangdong, Hainan and the central region of Heilongjiang, Jilin, Shanxi, Anhui, Jiangxi, Henan, Hubei, Hunan, because the partial data of Chongqing, Tibet, Qinghai is not available, the findings can not be used with Eviews software, so we select only Sichuan, Guizhou, Yunnan, Shaanxi, Gansu, Ningxia, Xinjiang, Guangxi, Inner Mongolia.

\subsection{Unit Root and Cointegration Tests}

We undertake the two testing methods include the same unit root tests LLC(Levin, Lin, Chu) and the different unit root test PP-Fisher for the1987-2010 panel data of the eastern, central and western regions. If they are rejected the null hypothesis of a unit root, then you can consider this sequence is stationary, the contrary is non-stationary. The results showed that: the variables of the original sequences are present unit root and are non-stationary series, when we tested the first difference of each variable, the test results are significant at the $1 \%$ level and rejecte the null hypothesis, which belong to same order stationary, the first difference of each variable sequence is a smooth sequence. Therefore, we can determine the import and export trade, FDI and economic growth may exist the long-term cointegration relationship, whether it exists or not, we need cointegration analysis.

Kao (1999), Kao and Chiang (2000) using the generalized DF and ADF test proposed the approach of test panel cointegration. We take Kao test, respectively undertake cointegration test for four groups of variables(LnGDP, LnEX, LnIMP and LnFDI), the results show that the four variables exist long cointegration relationship in eastern, central and west regions. It reveals in Table 1 by multivariate regression.

\subsection{The Comparative Analysis of Three Regions for Two Stages}

When China join the WTO, the regional economy develop rapidly, the eastern region's economy from the low income levels (average per capita GDP CNY 6200) rose to medium to high income level (average per capita GDP CNY 28000), central and western region from low income levels (average per capita GDP CNY 3300) rose to lower-middle income level (average per capita GDP CNY 14200). Therefore, the research bases on joining WTO, divides into two stages of development(1987-2001 and 2002-2010), compared with these two periods we can better conclude the effects change of foreign trade and investment on the economic growth.

Table 1. Compared with the effects of FDI, import, export on economic growth and two periods

\begin{tabular}{|c|c|c|c|c|c|c|}
\hline Area & \multicolumn{2}{|c|}{ Eastern area } & \multicolumn{2}{|c|}{ Central area } & \multicolumn{2}{|c|}{ Western area } \\
\hline Variable & $\begin{array}{c}1987-2001 \\
\text { Individual } \\
\text { fixed-effect }\end{array}$ & $\begin{array}{c}2002-2010 \\
\text { Individual } \\
\text { random } \\
\text {-effect }\end{array}$ & $\begin{array}{c}1987-2001 \\
\text { Individual } \\
\text { random } \\
\text {-effect }\end{array}$ & $\begin{array}{c}2002-2010 \\
\text { individual } \\
\text { random } \\
\text {-effect }\end{array}$ & $\begin{array}{c}1987-2001 \\
\text { Individual } \\
\text { fixed } \\
\text {-effect }\end{array}$ & $\begin{array}{c}2002-2010 \\
\text { individual } \\
\text { random } \\
\text {-effect }\end{array}$ \\
\hline & 5.4019 & 3.7236 & 6.5110 & 5.6401 & 5.6608 & 4.9396 \\
\hline $\mathrm{C}$ & $(51.7903)^{* * *}$ & $(14.8986)^{* * *}$ & $(29.0565)^{* * *}$ & $(32.2256) * * *$ & $(52.0603)^{* * *}$ & $(23.5123) * * *$ \\
\hline LnEX & $\begin{array}{c}0.3514 \\
(8.9590) * * *\end{array}$ & $\begin{array}{c}0.2693 \\
(3.7668)^{* * *}\end{array}$ & $\begin{array}{c}0.0295 \\
(0.4478)\end{array}$ & $\begin{array}{c}0.0972 \\
(2.2800) * *\end{array}$ & $\begin{array}{c}0.2020 \\
(4.0531)^{* * *}\end{array}$ & $\begin{array}{c}0.1969 \\
(3.2143)^{* * *}\end{array}$ \\
\hline LnIMP & $\begin{array}{c}0.0337 \\
(1.0536)\end{array}$ & $\begin{array}{c}0.2180 \\
(2.9796)^{* * *}\end{array}$ & $\begin{array}{c}0.2262 \\
(5.3907)^{* * *}\end{array}$ & $\begin{array}{c}0.3378 \\
(6.7980) * * *\end{array}$ & $\begin{array}{c}0.1366 \\
(3.7276)^{* * *}\end{array}$ & $\begin{array}{c}0.3086 \\
(6.1106) * * *\end{array}$ \\
\hline LnFDI & $\begin{array}{c}0.0255 \\
(1.6211) *\end{array}$ & $\begin{array}{c}0.2266 \\
(4.4909) * * *\end{array}$ & $\begin{array}{c}0.0412 \\
(1.9167) * *\end{array}$ & $\begin{array}{c}0.0933 \\
(2.8145) * * *\end{array}$ & $\begin{array}{c}0.0108 \\
(0.5621)\end{array}$ & $\begin{array}{c}0.1259 \\
(2.8733)^{* * *}\end{array}$ \\
\hline Observations & 165 & 99 & 120 & 72 & 135 & 81 \\
\hline Adjusted $\mathrm{R}^{2}$ & 0.9799 & 0.8657 & 0.8120 & 0.8802 & 0.9636 & 0.8003 \\
\hline F statistic & 616.7802 & 211.582 & 172.3758 & 174.9515 & 323.5138 & 107.8698 \\
\hline
\end{tabular}

Note: Number in brackets is the t-test value for the coefficient, *,**,** indicate that coefficient have passed the level of significance test respectively, by $1 \%, 5 \%, 10 \%$.

After China joined the WTO, different regional economy leapt rapidly in the eastern region from low income levels (average per capita GDP 6200 dollars) to high income level (average per capita GDP 28000 million).At the same time, the role of foreign trade and investment changed. According to the empirical results, it weakened exports and significantly strengthened imports. And foreign direct investment role promoted the economy gradually. With the accession to the WTO, the international competitive pressures coupled with a huge rise in labor costs, the contribution of eastern region's exports weakened (coefficient from 0.3514 down to 0.2693 ), while the eastern coastal state encouraged industry to the Midwest, whose role weakened exports to the economy 
and promoted import. With the increased level of economic development, FDI effects on economic growth of watching coefficient from 0.0255 to the 0.2266 , which changed significantly. Since joined the WTO, the eastern region, where had excellent geographical location and technical support, attracted large inflows of FDI, driving economic growth. However, it changed the order of internationalization patterns effects. Before joined the WTO, the order were exports, imports, FDI, this order becomes exports, FDI and imports now.

After the central region divided into two periods, from the rise in low-level (an average per capita GDP of CNY 3300 ) to the medium to low income (average per capita GDP in CNY14200), the export's promoting effect on economy becomes significant and the import also plays an enhanced role. With the improvement of the economic development, the central region's economy develops rapidly by using resources and national policy support, developing the export, promoting economic growth. But the central region is still in a middle income level. The import is still the region's economic growth engine. Central regions' promoting effect of FDI to the economy is inferior to the eastern region, but also appeared a small growth effect. After the accession to the WTO, tariff reduction and central policies to encourage FDI inflows promote the development of the economy to some extent, while the use of foreign capital level and the quality is not high. The order of the internationalization patterns to promote economic growth has changed from "import, FDI, export" before accessing the WTO to "import, export and FDI".

When the western region divides into two stages, the levels of economic development rise from low level to lower-middle income, slightly lower than the level of central region economic development, it still lag behind, the role of export promote a little in the economy, the role of imports increased significantly because of the western region's economic is in a backward level, the economy is still driven mainly by import, especially after joining the WTO, the western region grasps the opportunity of the western development and the lowering of tariffs after joining the WTO, and carries with Central Asia, Southeast Asia, Mongolia, Russia and other countries of trade, at the same time, the opening of the new Eurasian Continental Bridge, greatly improves the region's transportation, import trade advantages gradually reflected. When the economy of western region grows rapidly, it also carries out the western strategy and the corresponding policy measures to encourage capital from Hong Kong, Macao and other FDI to invest in the western region, which favorable promoting economic growth. We can see the effect sequence from the internationalization, the sequence before joining the WTO: export, import, FDI, while the sequence after joining the WTO: import, export, FDI.

Through the above analysis, the regions at different levels of economic development, the changes of economic growth factors (imports, exports and FDI) boosting the economic growth broadly were in line with theoretical expectations. Compared with two stages from 1987 to 2010, the developed eastern region's export trade promoted biggest in economy, but the role weakened in promoting the economy; the effects of import in relatively backward central and western region were greater than the eastern region, but the effect of import was enhanced; the FDI produce a weak positive effect on the economic growth; from the stages view, though the effect of FDI produce low function on promoting economic growth, it shows the positive effect gradually increase.

\section{Conclusions and Implications}

Research shows that from 1987 to 2010, whether before or after the accession to the WTO, It has a big gap between the level of eastern region's economic development and the Midwest region's economic development, therefore, the eastern region has a stronger export effect on economic growth, while the effect of import on promoting economic in Midwest regions is more obvious, the FDI of three regions produce minor positive effect on economic growth, there may be presence greater crowding-out effect. Compared with two phrases before and after accession to the WTO among three regions, each region at different levels of economic development, it has changed the effects on economic growth for import, export and FDI. We got several important conclusions: the role of export in eastern region is weakening, the role of import in eastern region is increasing; the export becomes significant role in promoting economic growth, the role of import is enhanced; there is little change for the effect of export in promoting economic growth in western region, and the role of import also enhanced in western region; FDI inflows on the role of economic growth are enhanced in three regions. The result of this change is consistent with the theoretical analysis expected.

The research shows that the effects of foreign trade and FDI in promoting economic growth are appearing cyclical changes as the stage of economic development changed, therefore, the mix of different foreign trade and FDI policy should be adjusted with the economic development. At this stage level, each region should be based on their own level of economic development, rationally adjust foreign trade and FDI policies. Relevant revelation showed as follows: 
(1) In the export side. For the developed eastern region, export growth effect decreased gradually, which means that the sustainability of export-oriented economic development strategy is being challenged, the developed eastern regions' export growth mode is in urgent need of transformation and upgrading of the cultivation of new advantage. Central region's export contribution still has some growth potential, and the western region's export contribution also has a tendency to decrease. It means that The Midwest uses the eastern's export driven growth model simply will be restricted. Limited of the low cost advantage in the Midwest can't completely offset the disadvantages of the geographical location.Therefore the central and western regions copying the export strategy of the eastern is difficult to get the same effect.

(2) In the import side. In the start stage of industrial cycle, import is the most important internationalization mode to promote the development of industry and plays a more important role to the relatively backward area. The empirical results show that the promoting effect of import on economic growth in the central and western regions have greater effect. The role of developed eastern region is relatively small; But look from development, eastern, central and western three areas' import growth effect are enhanced. This shows in China with large foreign exchange reserves, under the condition of the role of imports in the future there will be a great potential for growth. Even in the more developed eastern region, due to the large number of emerging industry development, so the import in the eastern region will still play essential roles in the industrial transformation and upgrading.

(3) In terms of utilization of inward FDI. According to the industry cycle theory, FDI at the beginning of the industrial development and regional economy has a more important role. But the empirical study shows that the role of FDI to promote economic growth in the three regions are all positive. The eastern region with good growth environment, its growth effect is greater than the central and western regions; In the western region, with its relatively abundant resources advantage, the promoting effect of FDI is greater than the central areas. From the empirical results of FDI, it's role is not bigger than the role of trade, FDI weak effect on promoting economic growth is different from our intuitive understanding that the role of FDI is much big, and this is crowding out effect of FDI on local enterprises. Therefore, the role of FDI increase still have larger space, especially on improving their quality. The future utilization of FDI can't depend on super-national treatment to attract FDI inflows. The FDI must be combined with foreign technology, intelligence, relying on local enterprise agglomeration of innovation resources and innovation ability raise to introduce high quality FDI, increasing interactive integration of foreign and domestic enterprises, in order to improve the economic growth.

(4) In outward FDI (OFDI). According to Dunning stage theory and industrial investment cycle theory, OFDI is the most important mode of internationalization in developed regions and the industrial higher developing stage. China's open economic development has already accumulated large foreign exchange reserves for OFDI, since the 2008 financial crisis, China's OFDI has seen rapid growth. Although OFDI in China has just started, due to insufficient research data limits the study, It can be foreseen both from the theory and practice of preliminary performance that the future development of China's OFDI will play an important role for China's economic growth and industrial transformation and upgrading.

\section{Acknowledgments}

We would like to thank anonymous referees for their comments. This research funded by Social Science fund of the Ministry of Education in China (11YJA790185, 12YJC790172) and by 2013 Grand project of National Social Science Fund in China (13\&ZD046), and supported by the department of international economics of Zhejiang University of Technology, and by Key Research Centre of Philosophy and Social Science of Zhejiang Province, Zhejiang Technological Innovation and Enterprise Internationalization Research Centre. All remaining errors are responsibility of the authors.

\section{Reference}

Blassa, B. (1978). Exports and economic growth: Further evidence. Journal of Development Economics, 5(2), 181-189. http://dx.doi.org/10.1016/0304-3878(83)90031-7

Cao, W. (2005). The empirical analysis of FDI on China's economic growth. World Economy Study, 8, 41-45. http://dx.doi.org/10.3969\%2fj.issn.1007-6964.2005.08.007

Cao, Y., Chen, X., \& Ma, Y. (2010). Urbanization, urban-rural income gap and economic growth-based on Chinese provincial panel data empirical analysis. Statistical Research, 3, 29-36. http://dx.doi.org/10.3969\%2fj.issn.1002-4565.2010.03.004

Coe, D., Helpman, E., \& Hoffmaister, A. (1995). North-South Spillover. European Economic Review, 39, 859887. http://dx.doi.org/10.1016/0014-2921(94)00100-E 
DeMello, L. R. J. (1999). Foreign direct investment-led growth: Evidence from time series and panel data. Oxford Economic Papers, 51, 133-151. http://dx.doi.org/10.1093/oep/51.1.133

Dunning, J. H. (1988). The electric (OLI) paradigm of international production: A restatement and some possible extension. International Journal of Economic of Business, 19(1), 1-31. Retrieved from http://papers.ssrn.com/sol3/papers.cfm?abstract_id=1794906

Fan, B., \& Wang, Y. (2004). The study on the relationship between import trade and economic growth. International Trade Issues, 4, 8-13.

Fan, B., Mao, X., \& Wang, S. (2005). Chinese exports contributed to economic growth empirical study: 19522003. International Trade Issues, 8, 5-9.

Feder. (1982). On exports and economic growth. Journal of Development Economics, 12, 59-73. http://dx.doi.org/10.1016/0304-3878(83)90031-7

Gao, T. (2006). Econometric analysis and modeling. Tsinghua University Press.

Jiang, J. (2004). Foreign direct investment mechanism in China's economic growth. World Economy, 1, 3-10.

Kueh, Y. Y. (1992). Foreign investment and economic change in China. China Quarterly, 637-690. http://dx.doi.org/10.1017/S0305741000046324

Kwan, A. C. C., \& Kwok, B. (1995). Exogeneity and the export-led growth hypothesis: The case of China. Southern Economic Journal, (61), 1158-1166. Retrieved from http://www.jstor.org/stable/1060747

Li, J., Chen, Y., \& Zhang, Z. (2005). The effects of trade on economic growth of regional differences. Finance \& Trade Economics, 5, 65-70.

Lin, Y., \& Li, Y. (2003). Exports and economic growth in China: Demand-driven analysis. Economics, 3, 779794. Retrieved from http://ibb.bnuep.com/upload/2011-5/201151610158.pdf

Liu, X. (2001). Cointegration and error correction model-Foreign trade and economic growth research. Nankai Economic Studies, 5, 53-56. http://dx.doi.org/10.3969\%2fj.issn.1001-4691.2001.05.011

Mao, X., \& Yao, Y. (2009). Foreign direct investment, foreign trade and economic growth-An empirical analysis on Eastern China. Industrial Technonlogy \& Economy, 9, 146-152. http://dx.doi.org/10.3969\%2fj.issn.1004-910X.2009.09.038

Shan, J., \& Sun, F. (1998b). On the export-led growth hypothesis; the econometric evidence from China. Applied Economics, 30, 1055-1065. http://dx.doi.org/10.1080/000368498325228

Shi, C., Wang, Y., \& Wang, K. (2003). China's foreign trade and eeconomic growth empirical analysis. Nankai Economic Studies, (1), 53-55. http://dx.doi.org/10.3969\%2fj.issn.1001-4691.2003.01.01

Song, Y. (2012). Investment development cycle theory test in China-Based on the level of economic development and foreign direct investment in empirical research. Contemporary Workers, 6, 88-91.

Vernon, R. (1966). International investment and international trade in the product cycle. Quarterly Journal of Economics, 80(2), 190-207. Retrieved from http://www.jstor.org/stable/1880689

Wang, X., \& Zhang, W. (2005). Empirical ananlysis on the relationship between foreign trade, FDI and economic growth in Yunnan. Yunnan Finance and Trade Institute, 3, 60-64. http://dx.doi.org/10.3969\%2fj.issn.1674-4543.2005.03.012

Wang, Z., \& Li, Z. (2004). Foreign direct investment, spillovers and endogenous economic growth. World Economic Papers, 3, 23-33. http://dx.doi.org/10.3969\%2fj.issn.0488-6364.2004.03.003

Xu, H., \& Lai, M. (2002). Export-Led Growth (ELG) empirical studies: Overview and comments. World Economy, (2), 43-49.

Xu, H., \& Luan, Y. (2005). The technology spillover effects of export trade: Based on the three sectors empirical study. The Journal of Quantitative \& Technical Economics, 9, 104-112. http://dx.doi.org/10.3969\%2fj.issn.1000-3894.2005.09.012

Yao, L. (2001). Foreign trade contribution on China's economic growth. Statistical Research, 9, $20-22$. http://dx.doi.org/10.3969\%2fj.issn.1002-4565.2001.09.004

Yao, L., \& Wang, L. (2011). Comparison of internationalization promotion patterns of region economic growth in China. International Journal of Business and Social Science, 2(13), 101-110. Retrieved from http://www.ijbssnet.com/journals/Vol._2_No._13_Special_Issue_July_2011/12.pdf 


\section{Copyrights}

Copyright for this article is retained by the author(s), with first publication rights granted to the journal.

This is an open-access article distributed under the terms and conditions of the Creative Commons Attribution license (http://creativecommons.org/licenses/by/3.0/). 